Article

\title{
Possibilities of Using the Tourism Area Life Cycle Model to Understand and Provide Sustainable Solution for Tourism Development in the Antarctic Region
}

\author{
Zygmunt Kruczek ${ }^{1, *}$, Michał Kruczek ${ }^{2}$ and Adam R. Szromek ${ }^{3}$ \\ 1 Department of Natural Environment Sciencies, Faculty of Tourism and Recreation, University School of \\ Physical Education in Krakow, 31-571 Krakow, Poland \\ 2 Unit of Biochemistry, Institute of Plant Biology and Biotechnology, Faculty of Biotechnology and \\ Horticulture, University of Agriculture in Krakow, 33-332 Krakow, Poland; kruczek.michael@gmail.com \\ 3 Department of Organisation and Management, Silesian University of Technology, 44-100 Gliwice, Poland; \\ aszromek@polsl.pl \\ * Correspondence: zygmunt.kruczek@awf.krakow.pl; Tel.: +48-602-126-282
}

Received: 15 October 2017; Accepted: 28 December 2017; Published: 1 January 2018

Check for updates

\begin{abstract}
An important problem for the development of tourism in the polar regions is the determination of the limit of tourist traffic that these regions can accept, without risking the degradation of the environment. One such region is Antarctica. This article describes the environmental conditions of Antarctica that decide its attractiveness for tourists, as well as its political and legal status. The factors that determine a tourist reception area of increasing intensity are analyzed. Based on the data of the International Association of Antarctic Tour Operators (IAATO), the volume of tourist traffic was determined, and environmental problems identified, which result from tourism development in Antarctica. The model of R.W. Butler-Tourism Area Life Cycle (TALC) — was used to analyze the development of tourism. By the middle of the second decade of the 21st century, the number of tourists in the Antarctic region exceeded 40 thousand, which seems to be the largest figure (the "boom phase" in the Butler cycle) in sheer numbers, and which resulted in the introduction of less tourist-friendly behavior, from the point of view of environmental protection. On the basis of IAATO data, the environmental problems that are a consequence of the development of tourism in Antarctica are identified. Reference is made to climate change affecting the area, and on the basis of the Butler cycle, the hypothetical limits of the further development of tourism are described.
\end{abstract}

Keywords: Antarctica; exploration; tourism; Butler cycle; development boundaries; sustainable development

\section{Introduction}

Antarctica and its surrounding waters together form one of the most inaccessible regions on planet Earth. It is considered to be the last great untouched wilderness on our planet, with wildlife and landscapes that show little direct evidence of the actions of mankind. However, in spite of this inaccessibility, it is increasingly becoming a travel destination. Tourists are attracted by the entirely different natural conditions, the incredible landscapes, and the unique natural phenomena.

The aim of this work is to analyze the forms and scale of tourism here, and to define the direction and priorities for the development of tourism within the Antarctic region. Another aim is to verify 
the credibility of the Tourism Area Life Cycle (TALC) model, with regard to polar regions, as a tool for analyzing the evolution of tourism, and for setting limits on the development of such tourism This paper is based on analysis of topic literature, statistical data published by the International Association of Antarctic Tour Operators (IAATO) and international tourist organizations, and our own observations. The result of our research is an attempt to forecast tourist traffic for the coming years, and the application of a model of the tourist evolution cycle to analyze the development of tourism in the Antarctic region [1-3].

\section{Literature Review}

Tourism in the polar regions has already been the subject of many publications [4-8]. The first papers to address the question of the environment, science and tourism in the Antarctic region were published in a special issue of the Annals of Tourism Research as long ago as 1994 [9]. Articles appeared that undertook analysis of the tourist traffic generated by both cruise ships and by flights over Antarctica $[10,11]$. The problem of the growing popularity of the region as a "last chance tourism" destination has often been considered [12,13]. Global changes in climate have triggered the desire to see this ice wonderland "before it's too late" [14]. One issue often discussed is how to assess the level of tourist traffic that the region can bear without damage to the natural environment [15-18]. In order to limit the flow of tourists, use was considered of the Limits of Acceptable Change (LAC) model [19], which had proved itself in national parks in the U.S. and Australia $[19,20]$. The number of tourists in Antarctica has been rising dramatically, especially in the last two decades [21,22]. Given the threat to the delicate ecosystem of Antarctica, a positive approach to tourists has also been considered. Various types of educational eco-tourism have been proposed in order to create "ambassadors" for the region [23-25].

Other papers indicate that one opportunity for limiting tourist traffic are the codes of practice introduced by the IAATO, which define ways to limit the number of tourists and groups by, for example, additional charges, but also by limiting the number of large cruise ships $[13,26]$.

The review of the literature presented indicates the importance of the principle problem of how to define the upper limit of tourist traffic in the Antarctic region. The authors listed [15-18] employed a variety of models, one of which was the LAC model [19]. This may have proved useful in national parks in Australia and North America, but no credible confirmation of its usefulness is evident for the fundamentally different Antarctic region. Definition of the limit of tourist development is crucial for the selection of instruments that ensure the number of tourists is kept at levels that are safe for the environment. This evidence, resulting from study of the literature, inspired the authors to verify the possibility of using R.W. Butler's TALC model [1] to forecast the development of tourist traffic in the region described, and to predict its volume. The model has been used in various parts of the world, where it was adapted to suit local conditions. The resulting research either confirmed [27-30], modified [31,32], or negated the model's credibility [2,33,34]. To date, the TALC model has not been tested with regard to the Antarctic or other polar regions.

The Tourism Area Life Cycle (TALC) model, which was published in 1980 and then revised by the author 20 years later [1], explains the development of tourist attractions through six developmental phases of tourist areas (including spa resorts). The original concept was based on two other economic concepts (stemming themselves from J.M. Keynes' economic development cycle model): W.W. Rostow's concept [35], and P. Kotler and R.E. Turner's concept [36]. For a quantitative definition of the degree of evolution of an area, the principle factor employed was the symptomatic variable, in the form of the number of visitors arriving in the area under research in a given time period (e.g., over one year). Figure 1 presents the next phases of the cycle: exploration, involvement, development, consolidation, stagnation, and decline or rejuvenation, which are described in numerous publications $[1,3]$. 


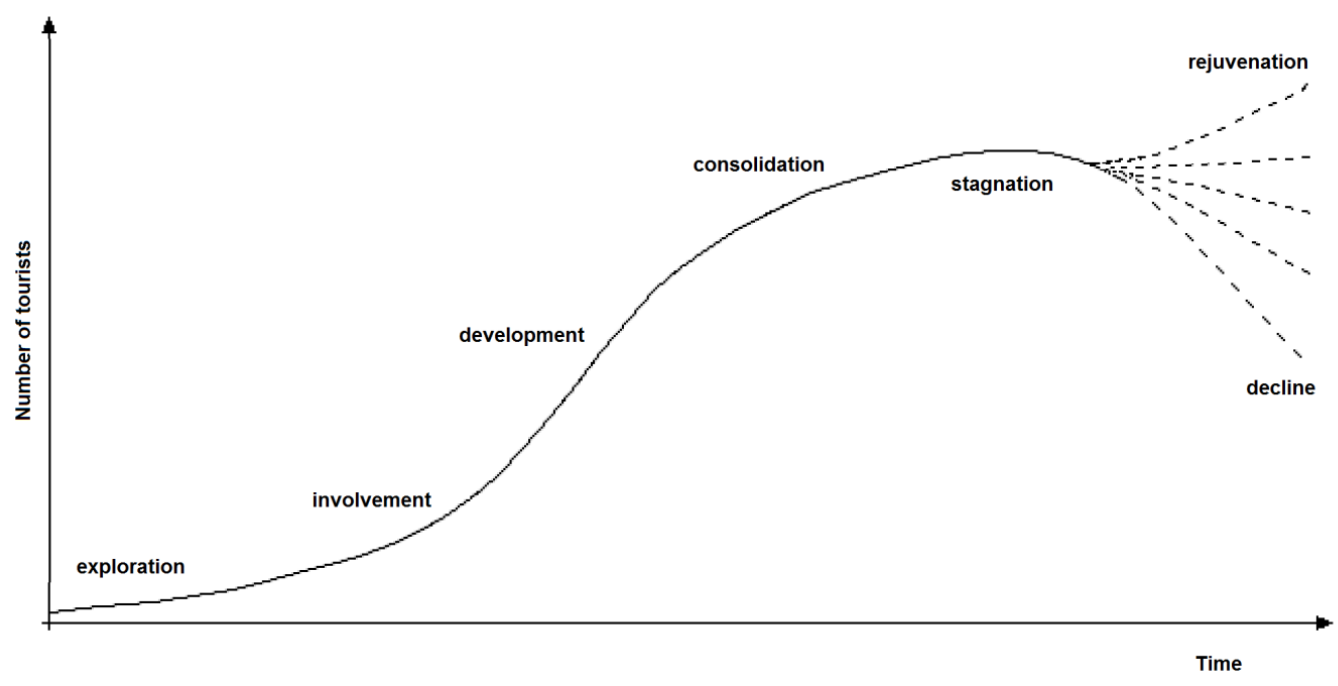

Figure 1. Phases in the Butler cycle with relation to protected areas (Source: [24] (pp. 5-12)).

Two decades after publication of the TALC model, R.W. Butler widened his concept to include eight characteristic elements on which the concept is based, and six years later he developed the concept by gathering the experiences of other researchers who were using his model [37]. Key additions to the concept included references to the weaknesses and strengths that the literature had mentioned over the past two decades, as well as proposed concepts that explained the reasons for development, change, limitations, and interference in a tourist area. R.W Butler lists eight named factors [38]:

- dynamism — change over time, one of the most characteristic features of tourist activity;

- process-a feature that characterizes the changes taking place in a tourist area, and which enables a model-based view of development;

- tourist absorption and capacity or development limitations-this model is based on the claim that if the number of visitors exceeds the tourist absorption and capacity, the quality of the experience of those visitors will decline;

- initiative factors-factors that cause change in a tourist area, e.g., innovation;

- management-it is crucial that emphasis is placed on the management of a tourist area as a whole (comprehensively), as many components in these areas lack management, even though they have separate resources and properties;

- long-term perspective-the necessity to take a perspective view of the development of an area, in the initial development phases, is both an indicator of the effectiveness of actions undertaken to delay the onset of the decline phase, and of intervention actions initiating a rejuvenation immediately after stabilization, which is typical for stagnation;

- spatial components-if there is a slowing down of development in an area, a locational shift of the tourist area is proposed, to sites in which development is starting from the beginning or is continuing;

- universal application —-the model was designed for all tourist areas, including specialized areas such as spa resorts.

Numerous publications refer to the concept by identifying schematic development similarities of different tourist areas, according to the R.W. Butler model. As a result, the model itself undergoes continuous development. Some articles provide proof confirming the veracity of the concept in different parts of the world, and even in different aggregate environments [33]; others point to imperfections in the model and the use of measures $[27,29,39]$, while others complement the concept $[31,32]$. 
One interesting view is cited by S. Weizenegger [3], which adds two more zones to the critical area (below and above the critical tourist capacity range), and which cites examples of introducing limitations in the form of high taxes for exceeding capacity, in order to implement protection for the area. Development of the area would therefore be limited to the first three phases, and would then take the form of a forced stagnation phase-but at the end of the development phase. It would appear, however, that uneasiness on the part of the local community wishing to continue with development would result in the lifting of such restrictive barriers, or would increase activity in the black economy.

J.O. Lundgren [40], meanwhile, refers to the dependence between the attractiveness of a tourist area and the tempo of its development. In the initial phases, the graph curve of theoretical attractiveness reaches a high level, which is surely one of the reasons for the rise in popularity of the area, while later, in subsequent phases, the theoretical attractiveness begins to drop. It is worth noting that the curve is almost a mirror image of the curve of visitor numbers, with regard to the average level at the intersection of the curves.

An interesting picture of the changes in individual phases is painted by S.W. Boyd [2], who modifies the TALC model by referring to the principles of sustainable development. He divides the cycle into several zones. The first zone, which covers the first two Butler phases, is defined as the sustainable zone, which places emphasis on ecological integration, as a state in which ecological and biological processes in an ecosystem community reach a state of self-sustainability. The second zone, conditional sustainability, is divided into two sub-zones. The first zone relates to the development phase, in which there is a striving for economic sustainability (that is simultaneous improvement in the quality of life and the environment), but with emphasis on economic growth and development, followed in the second sub-zone by a return to maintaining ecological integration. In the development phase, a slow decrease in tolerance of the surroundings begins, while in the consolidation phase (which is also the first phase which reaches the critical tourist capacity range of an area), an increase is observed in the intensity of factors that cause ecological tension. The third zone, which is above the critical level, is the unsustainability zone, in which ecological damage occurs. However, this zone is not reached by the theoretical model, although possible in reality.

The above concept is based on rather too much generalization, and it possesses a certain weakness. S.W. Boyd [2], just like R.W. Butler, assumed that the critical range of tourist capacity would not change during the whole cycle. It is difficult, though, to assume that with the increase in visitors, there would be no change in the capacity of accommodations, restaurants, spa facilities, and even green spaces, such as trails, paths, and parks, etc. Similarly, the zones of ecological tolerance, tension, and damage, as well as sustainability (or lack thereof), do not have to remain stable throughout the whole of the cycle. This suggestion is put forward by D. Weaver and L. Lawton [41] who criticize the determinism of the model, and put forward two possible solutions for achieving a balance between demand and supply, while retaining the critical capacity range. The first involves adjusting the level of supply to the level of demand-together with an increase in visitors to an area, the capacity to receive further tourists also increases. This does not mean, however, that reaching the critical range is excluded, as it is possible that the tempo of facility capacity increase is not adapted to the development tempo, or that the area's capacity limits are reached. The second solution is based on limiting demand to match a defined level of supply. In this case, the critical range, being unchanging, would not be reached unless there was a growth in the black economy circumventing the restrictions. D. Weaver and L. Lawton [41] propose applying one or several of the following restrictions:

- restrictions on places or norms regarding the permitted number of visitors;

- imposing development standards;

- introducing limits on the number of accommodation places and conditions;

- introducing zones, in which certain restrictions on tourism development apply;

- introducing bans on the expansion of infrastructure, e.g., airports;

- raising admission fees to tourist areas (e.g., visa fees), to a level corresponding to the desired reduction in demand. 
C.S. Johnston [42] meanwhile refers to three tourist eras in the area analyzed, and places the zone divisions onto the TALC cycle scale. Given that the tourist function is only developing during the two first TALC phases, he defined them as the so-called "Pre-tourism Era". He then defined the next three phases as the "Tourism Era". Following these phases, depending on whether the area sees rejuvenation or decline in the post-stagnation phase, comes a continuation of the Tourism Era, or the beginning of the "Post-tourism Era".

Confirmation of the development of a tourist area according to the TALC model can be observed in many destinations around the world, both individually as well as in groups covering many connected destinations with specific activity profiles present in the same area [30].

\subsection{The Antarctic Treaty}

The Antarctic is the only uninhabited continent, and its political and legal status is defined by an international agreement known as the Antarctic Treaty. Also known as the Antarctic Pact, signed in December 1959 by the 12 countries conducting research in the Antarctic, the treaty came into force in June 1961, during the 3rd International Geophysical Year (1957-1958).

The Antarctic Treaty System (ATS) is a set of complex arrangements, devised for the purpose of coordinating relations among states with respect to Antarctica. This includes the Antarctic Treaty itself, recommendations adopted at meetings of the Antarctic Treaty Parties, the Protocol on Environmental Protection to the Antarctic Treaty, and two separate conventions for the Conservation of Antarctic Seals (London 1972), and on the Conservation of Antarctic Marine Living Resources (Canberra 1980) [43].

This treaty states that in the interests of the whole of mankind, the Antarctic should be used only for peaceful purposes, principally scientific research and limited tourist exploration. Any scientific research must be the result of cooperation, and results of such research should be made available to all. The Antarctic Treaty covers an area of 52.5 million $\mathrm{km}^{2}$. The treaty was initially signed for a period of 30 years, up until 1991, but the "Protocol on Environmental Protection to the Antarctic Treaty", which was added to the treaty, extended its validity period for another 50 years. ("Protocol on Environmental Protection to the Antarctic Treaty", also known as the Madrid Protocol, 1991.) The Antarctic Treaty System, which manages the continent, is an extraordinary international partnership encompassing 50 countries, which has, for over 50 years, blocked attempts to seize parts of Antarctica via territorial claims made by a range of countries. It sets the standards for all human activity in Antarctica-governmental and tourism alike-and requires that anyone planning activities must first gain authorization or permission from a relevant national authority [44].

Coordination of tourism in the Antarctic region is conducted by the international organization IAATO, which defines the principles of travel safety and environmental protection. Detailed norms have been drawn up regarding the behaviour of tourists, safe distances to be maintained from particular animals, and limitations whose aim is to minimise the negative impact of tourism on the natural Antarctic environment. The Antarctic Treaty also adopted these principles as recommendations for scientists living in the Antarctic. The International Association of Antarctica Tour Operators, which was founded in 1991 by seven operators, has a mission to advocate and promote the practice of safe and environmentally responsible Antarctic travel. The IAATO now has 115 members, who work together to implement and develop operational procedures, guidelines, and membership requirements that fulfill their mission, while ensuring that visitors have a safe and enriching wilderness experience. The success they have achieved is unprecedented in the global tourism industry; to date, almost no discernible impact on the environment has been observed. Effective visitor management in Antarctica relies on continued collaboration between the industry, the Antarctic Treaty Parties, and environmental organizations [45].

\subsection{The Antarctic as a Region for Adventure Tourism}

In comparison to other ecosystems on Earth, the Antarctic is characterized by a wide variety of landscapes, climatic conditions, flora and fauna, and naturally-occurring phenomena. This variety in 
the Antarctic is viewed by tourists as highly exotic, and is the main factor in attracting travelers from all corners of the world [46].

Another tourist attraction in Antarctica is the opportunity to observe the Aurora Borealis. Yet another interesting feature is the icebergs, typical in the coastal regions of Antarctica. These can be of enormous size, several hundred kilometers across, and protruding 20 to $30 \mathrm{~m}$ above the water, with flat tabletop surfaces. There are also considerably higher mountains, which, while they do not cover such a large area, are formed in unique fantastical shapes. The Antarctic ice comes in a variety of hues: white, azure, blue, pink, green, and brown, depending on the types of marine plant life visible to the naked eye, and on the microorganisms in the ice itself.

Other spectacular Antarctic phenomena that are popular amongst tourists are active volcanoes and thermal waters. The most well-known is Erebus volcano and Deception Island, which is the peak of an ancient volcano from the archipelago of the Southern Shetlands. Inside the 12-km-wide caldera is a natural port, where thermal waters come to the surface. On Wiencke Island in the Palmer Archipelago, meanwhile, the abandoned military base at Port Lockroy has been transformed into a museum, post office and souvenir shop, visited by some 7 to 10 thousand people per year [47].

Over the last 20 years, new forms of active tourism have appeared. Mountain climbing is developing, principally in the Ellsworth Mountains, where the main goal is the highest peak in Antarctica-Mount Vinson. Climbing the mountain is necessary for those wishing to complete the "Seven Summits" challenge. Summer bases are now set up more frequently to deal with the tourist traffic. The most well-known is Patriot Hills, which handles tourists and climbers. One popular form of exploration is attempting to reach the South Pole by land, or crossing Antarctica via the Pole.

Table 1 shows adventure tourism activities, indicated by visitors to the Antarctic in the 2016-2017 summer season. Among them, the most often indicated are activities such as marathon runs, climbing the Vinson Massif, and visiting Emperor penguin colonies, as well as skiing, mountaineering, skydiving, and cycling.

Table 1. Types of activities participated in by tourists visiting the Antarctic in the 2016-2017 season.

\begin{tabular}{cc}
\hline Type of Activity & Number of People \\
\hline Marathon & 113 \\
Vinson Massif & 111 \\
South Pole Fly-in & 71 \\
Deep Field Experiences (Camping, skiing, mountaineering, skydiving, cycling, etc.) & 53 \\
Emperor Penguin Colony Visits & 50 \\
Last 1-2 Degree Expedition & 43 \\
South Pole Motorised Expedition & 15 \\
South Pole Ski Expedition & 12 \\
Antarctic Crossing & 12 \\
Deep Field Flights (e.g., to Pole of Inaccessibility) & 4 \\
\hline
\end{tabular}

IAATO Overview of Antarctic Tourism: 2016-2017 Season and Preliminary Estimates for 2017-2018. Source: https: / /iaato.org/ current-iaato-information-papers, (accessed on 19 November 2017) [48].

The Polish Henryk Arctowski polar base, founded in 1977, is one of the most commonly visited places in Antarctica, with an estimated 3000 people visiting annually. [49]. The popularity of the Arctowski Base is due to the mild climate, and to the location on King George Island, which can be easily reached by sea and on which a helicopter landing site has been established. This ease of access results in an influx of tourists, in particular passengers on vessels sailing from Ushuaia or Punta Arenas. It is also worth noting the open and hospitable attitude of the base personnel, who are happy to show tourists around the area, serve up coffee, and sell maps, postcards and souvenirs. Depending on visitors' preferences, the base has four routes, varying in difficulty; the most popular place is the penguin colony. The base also monitors the effect of tourist traffic on the natural environment of King George Island [18,46]. 


\subsection{The Development of Tourist Exploration}

Antarctica, today sometimes called the 'continent of science and tourism' [50,51], was discovered in 1826 by a research expedition led by Fabian Gottlieb von Bellingshausen, and the continent was first explored by, amongst others, Edward Bransfield, James Weddell, Charles Wilkes, and James Clark Ross. A great contribution towards the exploration of the continent was made by whalers, who came to the region to hunt seals and whales. The South Pole was first reached on the 14 December 1911 by the Norwegian Roald Amundsen, after a dramatic race against a British team led by R.F. Scott.

The first visits by tourists began in the late 1950s. In December 1956, a Chilean plane with 66 passengers on board made the first flight over the continent, and in October 1957, Pan American Airways organized a tourist flight to Antarctica, including a landing. Over the years, trips to the region organized by travel agencies became more and more common (especially from the U.S., Canada, the U.K., Germany, Italy, Spain, Chile, Australia, and New Zealand), which to a large degree contributed to the creation of scientific research bases, often visited by the tourists.

At the end of the 1960s, Antarctica began to be explored from the sea. The first 200 tourists sailed there on board an Argentinian ship as early as 1958 [19], while the 1970s saw a large scale increase in this traffic. Most tourists sail to the region from Ushuaia in Argentina or Punta Arenas in Chile. Another port of departure for Antarctic cruises is Port Stanley in the Falkland Islands. The eastern regions of Antarctica can be reached from ports in New Zealand or Australia. The number of ships and passengers has risen, from two cruise liners in the mid-1980s, carrying 3000 annually, to around 40 ships carrying a total of 24,000 passengers in the 2005-2006 season.

Apart from private yachts, cruises to the Antarctic principally involve three types of vessels:

$>$ tourist cruise ships (mainly Russian) hired by western companies organizing excursions for more demanding customers, carrying around 100 people.

$>$ larger, more comfortable cruise liners, carrying some 300 people.

$>$ gigantic liners with a capacity of several thousand passengers (e.g., the Princess Cruises vessel "Princess Star").

The last of these three first appeared in the Antarctic in the year 2000, but the number of passengers on board makes disembarking impossible, so only tourists travelling in the first two types of vessel actually make landfall.

As noted earlier, the first pleasure flights over the Antarctic began in the late 1950s. In the years 1977-1980, commercial airlines from Australia and New Zealand carried out 44 flights over the Antarctic, carrying a total of 11 thousand passengers [21]. Today, the airlines Qantas and Air Zealand offer flights over the Antarctic, and carry some 10,000 people per year. In recent years, advances in aircraft technology have brought a dramatic increase in tourism, even to the interior of the continent. The discovery of a natural landing site of smooth ice, free of snow, at the foot of the Patriot Hills in the Ellsworth Mountains, has enabled large transport aircraft to land bringing in groups of tourists.

According to IAATO principles, the number of people on land at any one time should not exceed 100. This is to ensure that wild animals are not inadvertently scared off. However, it is important to note that it was tourists to Antarctic bases in the 1980s who first forced base personnel to respect the recommendations on environmental protection, sometimes appealing to governments to ensure that members of personnel cleaned up the area around the bases. In addition to this type of social pressure, tourists are more frequently becoming ambassadors for the whole of the Antarctic, spreading the word about the need to protect the continent [23-25]. What is more, tourist traffic also has a purely practical role, as tour operators often help individual bases with logistical issues.

The best conditions for tourism development, in terms of climate and logistics, are on the Antarctic Peninsula. Most scientific bases are also located here. Tourist traffic is concentrated around the research stations, which are an additional attraction for visitors. A visit to a base provides an insight into life at the research station, the conditions in which the researchers work, and encourages interest in the research issues they face. Tourist agencies purposely show visitors the research stations, even though 
they are unsuited to receive tourist traffic. After such visits, many tourists note the insufficient number of toilets and the limited access to meals, postal services, and opportunities for purchasing souvenirs. Some also expressed an interest in scuba diving, skiing, or overnight accommodation [49].

The geographical distribution of tourism on the Antarctic Peninsula can be divided into several sub-regions. These are:

- The South Orkney Islands, together with Laurie and Coronation Islands

- Elephant Island and the surrounding islands

- The South Shetland Islands, together with Deception Island, Livingston Island, King George Island, Low Island, and Smith Island

- The Antarctic Peninsula, east of Cape Dubouzet ( $\left.6316^{\prime} \mathrm{S}, 5703^{\prime} \mathrm{W}\right)$ to the James Ross Islands

- The northern part of the Antarctic Peninsula, with Cape Dubouzet (63 16 S, $5703^{\prime} \mathrm{W}$ ) to the Lemaire Channel

- The south-eastern part of the Antarctic Peninsula, from the northern end of the Lemaire Channel to the region of Marguerite Bay (67 34' S).

\section{Results}

\subsection{Directions and Limitations on Further Tourism Development}

The polar ecosystem is particularly sensitive to external interference, including changes caused by the expansion of tourism [52]. The threat from mass tourism is due to the frequency of visits to relatively small areas, which are usually of high ecological importance. Studies conducted at the Arctowski base indicate that the recommendations and warnings given to tourists about the correct way to behave at the station were often not fully adhered to [49].

Tourism can also result in pollution of the natural environment. Sewage, waste water, and also petrol required for transport can cause greater changes in Antarctic species than in organisms living in milder climates.

A report by the Intergovernmental Panel on Climate Change (IPCC) in 2007 shows the complex character of climate changes in the Antarctic. Changes in air temperature over the last 50 years (according to weather station research) show a clear, strong tendency towards warming. More precise research, however, has shown that the Antarctic is warming unevenly (Figure 1). The western part of the continent is experiencing deglaciation, while in the eastern part a slight thickening of the ice layer may even be observed, accompanied by a drop in air temperature. Analysis of data from weather stations from the last 30 years shows that 12 stations have seen a rise in temperature, while seven have seen a drop. At only two stations was the drop in air temperature of any statistical importance [53]. Despite the ambiguous changes in temperature, the IPCC is of the opinion that Antarctica is warming at a similar pace to the rest of the planet.

The temperature changes are accompanied by changes in the ice cover around the continent. Surrounding the land mass, there are areas where the ice sheet is retreating earlier; however, at the same time there are seas where the period of ice cover is actually extending. The Ross Sea is seeing a prolonging in ice cover, while the Bellingshausen and Amundsen Seas are experiencing a shortening in the period of ice cover (Figure 2). In both cases the observed tendencies are statistically important. This warming may assist in the development of tourism. The length of available coast is increasing, while the smaller range and density of pack ice makes access from the sea easier. The area of land free of ice is also increasing, while the period of air temperatures more tolerable for tourists is extending. 


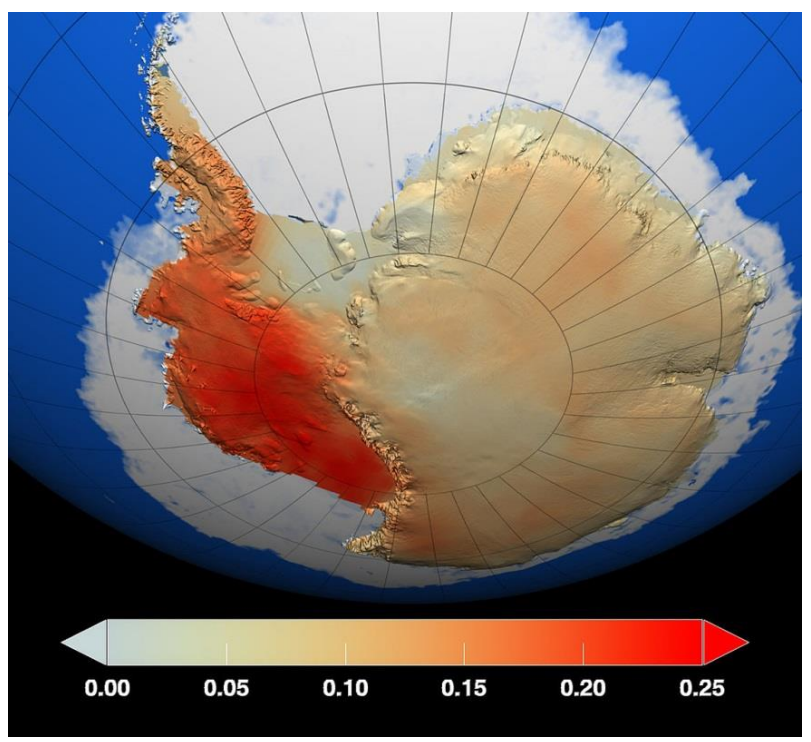

Figure 2. Antarctic surface temperature change tendencies, according to measurements taken in the years 1957-2006 (Source: [54]).

Antarctica is also experiencing a continual increase in the levels of carbon dioxide $\left(\mathrm{CO}_{2}\right)$ in the atmosphere. This is producing a range of negative effects on the environment and the ecosystem. Ever-increasing amounts of carbon dioxide are being dissolved in the sea water, resulting in a rise in acidity levels. As a consequence, the survival of all sea organisms that build calcium carbonate shells or skeletons is under threat. According to the IPCC, this will have a negative impact on the biocoenosis of the ocean as a whole, and will disrupt the existing food chain. Although the whole of the Antarctic is protected by international treaties, it turns out that the rise in temperature has already caused krill stocks to halve. On the other hand, the warming of the oceanic waters around Antarctica has brought an influx of new species, which may in turn cause a re-enriching of the ocean ecosystem. The above-mentioned negative effects on the diversity of species in the polar ocean will principally have economic consequences, while tourism will remain largely untouched. It is tempting to state that climate changes, resulting in global warming on a macro scale, will probably lead to an intensification of tourist traffic in the area described.

\subsection{TALC Model and Tourism Growth Forecast}

Antarctica is an important world testing area for the implementation of so-called 'sustainable tourism'. [55] R.W. Butler (1991) defined sustainable tourism as tourism that is developed and maintained in such a way, and on such a scale, as to be both viable over an indefinite time period and to not cause changes to the natural environment in which it operates. Disrupting this state of "balance" makes progress, and the success of other initiatives and processes, impossible. It would appear that tourist traffic to the Antarctic, which has been increasing slowly since the 1970s, is reaching an upper limit, in terms of the ability to receive and service the number of visitors. However, the continuous development of tourism potential (infrastructure and means of transport) is artificially shifting the conventional critical balancing point between tourist absorption and capacity. What is more, the limited available land area on the continent, as well as the changeability in the rise of tourist numbers visiting the Antarctic, makes us wonder what prospects there are for tourism development in the region.

Analyzing IAATO data (Figure 3) depicting the number of visitors to the region in the years 1992-2015, it is difficult to not be under the impression that the increase is following the well-known model devised by R.W. Butler, who published the first principles of the tourist area development model, to be followed a year later by the TALC model [1] as we know it today. 


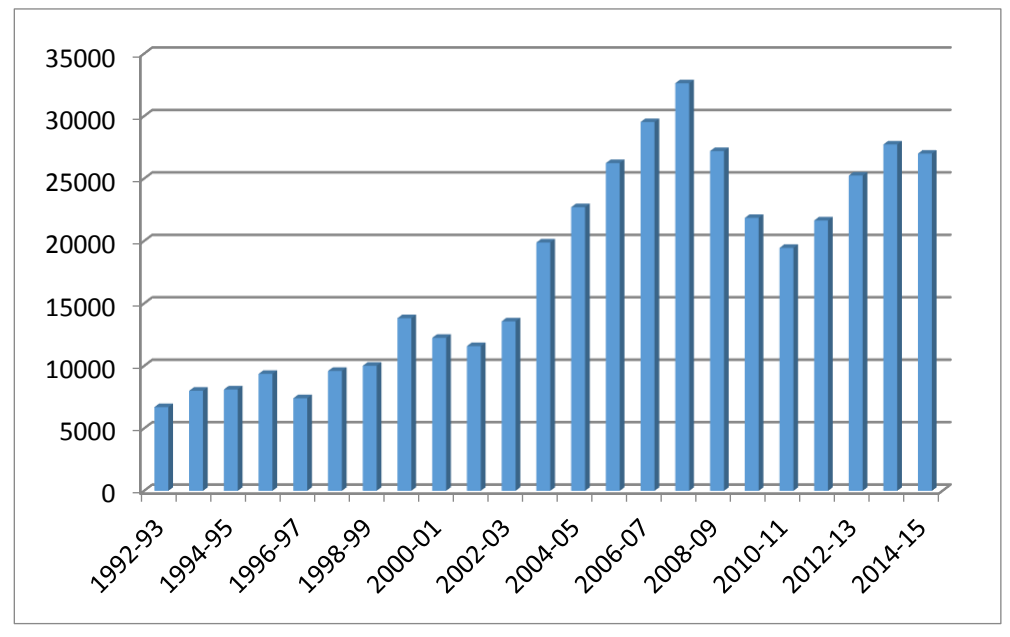

Figure 3. Trends in tourism development in the Antarctic, in the years 1992-2015, showing the number of air and sea passengers disembarking. (Source: authored analysis based on IAATO data).

At the beginning of the 21st century, it was forecast that by 2010, the number of tourists to the Antarctic in one season would grow to 20 thousand. Based on IAATO estimates (Figure 3), it can be seen that tourist traffic reached a record volume in the 2007-2008 season, when 32,600 tourists disembarked on Antarctica [26]. In subsequent years, the number of tourists fell to 19,500 in the 2010-2011 season (probably due to the worldwide financial crisis), and then grew to 27,000 in 2015. To the number of those disembarking, we must also add around 10,000 passengers on large cruise liners approaching the continent from the ocean, but without disembarkation. The British Antarctic Survey also gives similar estimates, according to which the total number of tourists in the early 1990s, including cruise liner passengers, reached between 9,000-10,000, while in the 2007-2008 season this had risen to 46,000. The number of tourist providers offering trips to the Antarctic has also risen, and currently stands at around 100, which is seven times more providers than 16 years ago. IAATO data shows more than 200 locations on the Antarctic Peninsula (including 20 research stations) visited by tourists. Analysis of the data, meanwhile, reveals that tourist visits are concentrated on, at most, 35 locations. The British Antarctic Survey, which monitors the volume of tourist traffic in Port Lockroy, puts the number at some 10,000 visitors in the summer season. The effects of this tourist traffic on the regions visited are starting to be seen on many levels, in particular relating to environmental changes caused by tourists [19].

The largest proportion of visitors travelling to the Antarctic is citizens of the U.S., over one-third of all tourists. The majority of these tourists are passengers on cruise liners belonging to North American travel agencies. In the 2016-2017 season, tourists from China came in second place (16\%), followed in third place by Australians (10\%). There are also a significant number of tourists from the U.K. (9\%) and from Germany (9\%). Other countries at the top of the list include Canada, France, The Netherlands, and Switzerland [45].

By applying the principles of TALC to the development cycle of the Antarctic tourist area, we can consider the period from 1958 (the first disembarkation of tourists) to the early 1990s as the "exploration" phase (Figure 1). This is due to the appearance of the first tourists, who, captivated by the area, found in it characteristics that decided its attractiveness as a tourist destination. The notion of virgin territory, where no man had set foot, definitely allowed for a certain degree of assimilation of the Antarctic as one of the last places untouched by mass tourism. The lack of infrastructure, while it must have caused difficulties, was not an obstacle to the exploration of the continent, and was surely most often seen as a strength. 


\subsection{Forecasting the Limit of Tourist Traffic}

The 1990s brought an increased number of tourists, from several thousand to 10 thousand per season. This is the "involvement" stage, when the first legal and organizational framework of Antarctic tourism was assembled. The first decade of the 21st century saw a continual upward trend in the amount of tourist traffic, which currently stands at a level four times that of the year 2000. This is the typical "development" phase in the Butler cycle. This may be followed by a "consolidation" phase and then a "blooming" of tourist activity—in other words, the peak period. Taking into consideration all formal limitations on tourist traffic, as well as logistical barriers, the current approximate number of 40,000 tourists in one season is the upper limit of tourist traffic reception in the region. Clearly these are only conjectures, based on existing concepts of tourist area development, and it is therefore also worth underlining the weaknesses of this hypothesis. Tourist activity in the area, usually measured by the proportion of inhabitants earning a living from the tourism industry, here requires a somewhat different point of reference. This time it is not residents who receive income from conducting this form of activity, but transport firms and specialized tour operators spread around the region, who are capable of organizing trips to this beautiful yet dangerous area. The Antarctic, therefore, has exceptional circumstances governing the development of tourist activity, which are difficult to identify using the tools available today. A key tool, therefore, is the meaningful data on the number of visitors to the area and the amount of excursions organized per year. This data plays a crucial role in the symptomatic variable illustrating the variation of tourist traffic. However, via this method, even hypothetical ex ante indicators of the individual phases of area development, according to the R.W. Butler model, become much more difficult to interpret.

During research into an explanation for the variation in the number of tourists visiting the area, analysis was made of many factors that may influence such a change. It was noticed that among these factors, economic aspects were found to play a key role. Analysis of the variability in visits to Antarctica showed a clear drop in the upward tendency in the years 2009 to 2011. Knowledge of the profile of those visiting the region, however, reveals how the world economy has a significant influence on tourism in the Antarctic.

Per capita GDP data (in current U.S. dollars) from The World Bank on all countries in the world, between 1960 and 2014, shows that three countries in particular had the greatest effect. The economies of the U.K., the U.S., and Germany had the most significant influence on the number of visitors, which correlates to the division by nationality of visitors to the region, although not in the same order. The convergence of changes to the per capita GDP of the British economy in the years 1992-2014, with the variation in the number of expeditions and visitors to the Antarctic is the highest, at $96 \%$ $(r=0.9809, p<0.05)$, while the U.S. economy shows a convergence of $89 \%(r=0.9449, p<0.05)$, and the German economy shows 77\% $(r=0.8747, p<0.05)$. The convergence indicators were established on the basis of Pearson linear correlation coefficient values, and on statistical tests of the significance of the correlation coefficient. These models show a very strong correlation between the estimated functions and the empirical data, which both indicate the high quality of the parameter estimation process in both models, as well as their high reliability.

By estimating the regression function for (1) numbers of excursions to Antarctica, and (2) numbers of visitors, on the basis of explanatory variable forecasts (GDP per capita for the U.K., U.S., and German economies), a smoothed forecast of the development of tourist traffic in the region was achieved (Figure 4). This shows that if the current economic growth trend in the U.K., U.S., and Germany continues, the number of organized excursions in the next five years will reach around 376 per year (in 2021) $\left(R^{2}=0.9647\right)$, and the number of visitors to the region per year will reach around 36,600 in the year $2021\left(R^{2}=0.9593\right)$.

$$
\mathrm{y}_{\mathrm{t}}^{\text {Voyages }}=-97,0103+0,0005 \mathrm{x}_{\mathrm{USA}}+0,0071 \mathrm{x}_{\mathrm{UK}}+0,0008 \mathrm{x}_{\mathrm{G}}
$$

$$
(18,1906)(0,0013) \quad(0,0012) \quad(0,0009)
$$




$$
\mathrm{y}_{\mathrm{t}}^{\text {Visitors }}=-7195,54-0,1441 \mathrm{x}_{\mathrm{USA}}+1,0343 \mathrm{x}_{\mathrm{UK}}-0,0977 \mathrm{x}_{\mathrm{G}}
$$

$(2006,95) \quad(0,1450) \quad(0,1350) \quad(0,0963)$

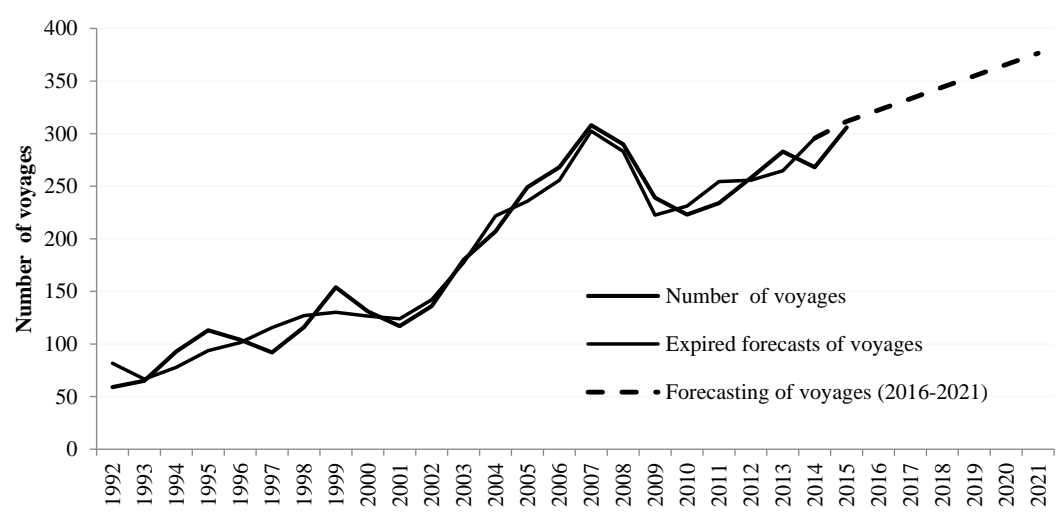

Figure 4. Forecasted number of excursions. Source: Author's calculations.

This forecast, while it is burdened with the assumption of ceteris paribus, which is difficult to accept in a volatile world economy, paradoxically has relatively high determination coefficients and low expired forecast errors, therefore supporting its reliability. The forecast does not take into consideration random fluctuations, but describes a general tendency.

As can be seen in Figure 4, the forecasts suggest a continuation of the long-term tendency to date, however, the number of visitors and excursions will not change as dynamically as in the first decade of the 21st century, which may in fact indicate a change in phase and the inevitable approach to the consolidation and blooming phases, reaching a critical tourist volume in following decades.

The Weizenegger theory [3] can be applied to the Antarctic in its entirety. This assumes that in protected areas, such as national parks, limitations on tourist traffic can be implemented by imposing high taxes for the exceeding of the area's capacity. This is to support the aims of protected area status. Development in such a place would therefore be restricted to the first three phases in the Butler cycle, and would then take the form of a forced blooming phase in the final stages of the development phase (Figure 5).

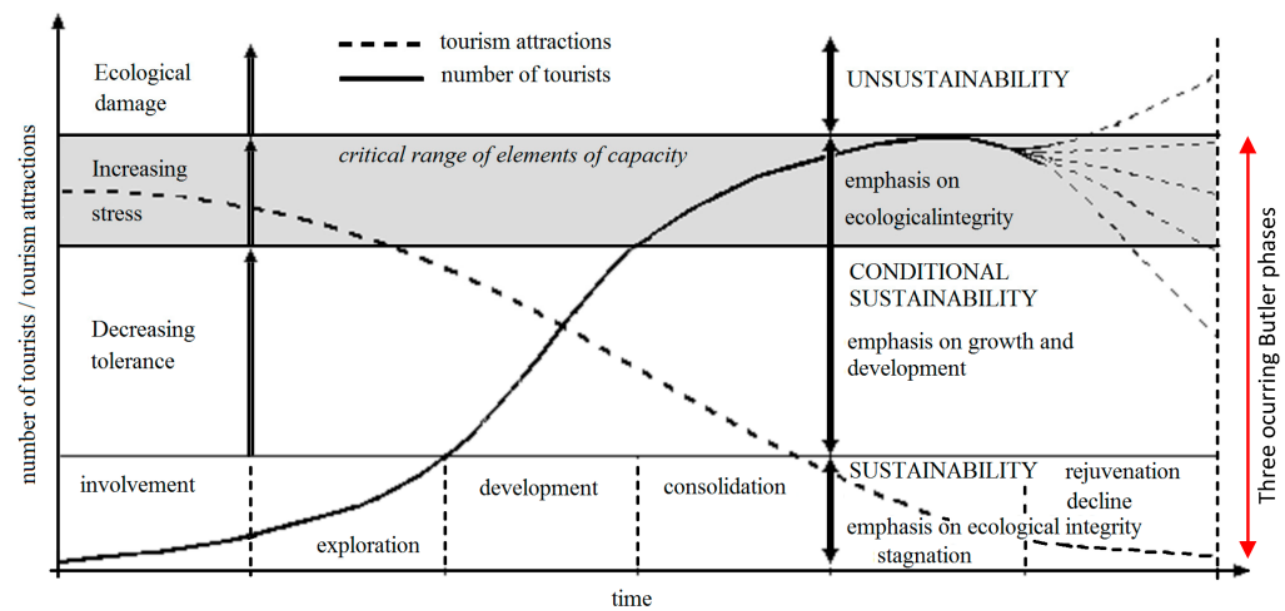

Figure 5. Sustainable development and the Tourism Area Life Cycle (TALC). (Source: [56]).

A continuing tendency towards an increase in the number of visitors to the region may be noticed, despite considerable fluctuations in the years 2000-2009. The trend in the forecasted period (i.e., after 2015) shows a slightly slower growth factor than in the years 1992-2008, which, according to the TALC 
model, may indicate a transition to the stabilization phase. However, as this can only be confirmed post factum, it remains merely a hypothesis that cannot currently be verified. This may therefore mean that the explanation of the changes in the number of visitors, with regards to accepted financial variables, is convergent with the general development of the region, as dictated by the TALC model.

\section{Conclusions}

In addition to "traditional" tourism, the polar regions of the Arctic and the Antarctic also possess good conditions for a variety of types of trekking and extreme sports, providing an escape from everyday life and an opportunity to tackle extremely harsh conditions. They also offer the chance to reach places where no one (or almost no one) has set foot, and to experience hunger, pain, risk, fear, euphoria, and exaltation, and finally, to be a unique "pioneer", with the feeling of separation from the everyday "normal" world [56]. The polar regions, therefore, are a challenge for providers of so-called adventure tourism, but the Antarctic is the only remaining wilderness on our planet which provides the opportunity to undertake a voyage of discovery.

It would appear that appropriate control of tourism development in the Antarctic can ensure the harmonious coexistence of tourists, scientists, and nature, the latter being a resource of the highest order.

The lack of a local population in the Antarctic, and the actions of the IAATO to restrict the extent of tourist traffic, together create a chance for the implementation of this model of tourism development in the Antarctic. It will remain a niche destination that is expensive enough to limit mass tourism, and excursions to this most difficult of regions will only be organized by experienced tourism providers.

The forecasts given in this paper for the development of tourism in the region are based mainly on economic factors, and indicate a continuation of the long-term tendency to date. However, the number of visitors and excursions will not change as dynamically as in the first decade of the 21st century. This development is in line with the change in the development phase according to the Butler TALC model, and is moving inexorably towards the consolidation and stagnation phases, while at the same time reaching critical tourist capacity in the coming decades. Protection of the environment from excessive exploitation may be served by applying the Weizenegger theory [3], which assumes that in protected regions such as Antarctica, limits on tourist traffic can be implemented by the imposition of high taxes for exceeding the region's capacity. Development in such a destination would therefore be limited to the first three phases of the Butler cycle, and then take the form of a forced stagnation, but at the final level of the growth phase. This is confirmed by Weaver and Lawton [41] in their work, which indicates the possibility that an incomplete TALC model cycle could occur.

Bearing in mind the upper limits calculated in our paper for the number of tourists that can explore the delicate Antarctic ecosystem, it is worth considering the possibility of implementing a tourist traffic management system, which would ensure controlled development of the region. One way would be the introduction of an annual limit on tourist numbers for tour operators, similar to the system followed in the Himalayan Kingdom of Bhutan $[57,58]$. This limit would be divided amongst the IAATO, in such a way as to ensure that the total number of permits issued did not exceed the limit. In the case of Antarctica, the problem is the lack of borders and a border guard service to monitor tourist traffic. Another option would be to tax tour operators and to use the fees collected to create a tourist traffic monitoring system. However, this system also has its drawbacks, as the administrative body collecting the fees for the purpose of monitoring traffic would also be funded by the fees collected. This would entail the signing of additional international treaties, and would increase the risk of changing the ecological goal to an economic one. Such cases have already been noted in the literature, regarding limitations on the number of climbing expeditions to the world's highest peaks [59], where the countries administrating the trails to the peaks receive considerable income from fees, as a result of which it is not in their interest to limit tourist traffic.

It is not only exceeding the limits of tourist numbers which is a threat to the ecosystem, but also the behavior of the tourists themselves. In order to limit tourist anthropopressure, it is important 
to focus on educating tourists through the presence of appropriately-trained guides, to ensure strict adherence to the principles of Guidance for Visitors to the Antarctic.

It would seem that favorable conditions exist to focus and regulate tourist exploration according to the principles of sustainable development, so that the unique Antarctic ecosystem remains intact [46], and becomes a destination only for exotic tourist exploration.

Acknowledgments: This paper was published as part of the research project "A business model for spa resort enterprises" Nr 2017/25/B/HS4/00301, supervised and financed by the National Science Centre in Kraków.

Author Contributions: The three authors contributed equally to this work.

Conflicts of Interest: The authors declare no conflict of interest.

\section{References}

1. Butler, R.W. The Concept of a Tourist Area and Cycle of Evolution: Implications for Management of Resources. Can. Geogr. 1980, 24, 5-12. [CrossRef]

2. Boyd, S.W. The TALC Model and its Application to National Parks: A Canadian Example. In The Tourism Area Life Cycle, Applications and Modifications; Butler, R.W., Ed.; Channel View Publications: Clevedon, NY, USA; Buffalo, NY, USA; Toronto, ON, Canada, 2006; Volume 1, pp. 119-138.

3. Weizenegger, S. The TALC Model and Protected Natural Areas: African Examples. In The Tourism Area Life Cycle, Conceptual and Theoretical Issues; Butler, R.W., Ed.; Channel View Publications: Clevedon, NY, USA; Buffalo, NY, USA; Toronto, ON, Canada, 2006; Volume 2, pp. 124-137.

4. Johnston, M.E. Polar Tourism Regulation Strategies: Controlling Visitors through Codes of Conduct and Legislation. Polar Rec. 1995, 33, 13-20. [CrossRef]

5. Johnston, M.E.; Vikens, A. Polar tourism implications and management. Ann. Tour. Res. 1997, 24, 1013-1015. [CrossRef]

6. Stewart, E.J.; Draper, D.; Johnston, M.E. A Review of Tourism Research in the Polar Regions. Arctic 2005, 58, 383-394. [CrossRef]

7. Snyder, J. Tourism in the Polar Regions: The Sustainability Challenge; United Nations Environment Programme: Nairobi, Kenya, 2007.

8. Hall, C.M. Tourism and environmental change in Polar Regions: Impacts, climate change and biological invasion. In Tourism and Change in Polar Regions: Climate, Environments and Experiences; Hall, C.M., Jarkko, S., Eds.; Routledge: New York, NY, USA, 2010; pp. 42-70.

9. Smith, V.L. A Sustainable Antarctic: Science and Tourism. Ann. Tour. Res. 1994, 21, 221-230. [CrossRef]

10. Bauer, T.G. Tourism in the Antarctic: Opportunities, Constraints, and Future Prospects; Haworth Hospitality Press: Binghamton, NY, USA, 2001.

11. Hall, C.M.; Johnstone, M.E. Polar Tourism: Tourism in the Arctic and Antarctic Regions; John Wiley and Sons Ltd.: Chichester, UK, 1995.

12. Haase, D.; Lamers, M.; Amelung, B. Heading into uncharted territory? Exploring the institutional robustness of self-regulation in the Antarctic tourism sector. J. Sustain. Tour. 2009, 17, 411-430. [CrossRef]

13. Lamers, M.; Eijgelaar, E.; Amelung, B. Last chance tourism in Antarctica-Cruising for change? In Last-Chance Tourism: Adapting Tourism Opportunities in a Changing World; Lemelin, H., Dawson, J., Stewart, E., Eds.; Routledge: London, UK, 2011.

14. Lemelin, H.; Dawson, J.; Stewart, E.J.; Maher, P.; Lueck, M. Last-chance tourism: The boom, doom, and gloom of visiting vanishing destinations. Curr. Issues Tour. 2010, 13, 477-493. [CrossRef]

15. Hall, C.M. Tourism in Antarctica: Activities, impacts and management. J. Travel Res. 1992, 30, 2-9. [CrossRef]

16. Enzenbacher, D. Tourists in Antarctica: Numbers and Trends. Polar Rec. 2009, 28, 17-22. [CrossRef]

17. Davis, P. Antarctic Visitor Behavior: Are Guidelines Enough? Polar Rec. 1995, 31, 32-334. [CrossRef]

18. Stonehouse, B.; Crosbie, K. Tourist Impacts and Management in the Antarctic Peninsula Area. In Polar Tourism: Tourism in the Arctic and Antarctic Regions; Hall, C.M., Johnston, M.E., Eds.; Wiley: Chichester, UK, 1995; pp. 217-233.

19. Davis, R.B. Beyond guidelines. A model for Antarctic Tourism. Ann. Tour. Res. 1999, 26, 516-533. [CrossRef]

20. Lucas, R.C.; Stankey, G.H. Role of Research in Applying the Limits of Acceptable Change System. In Proceedings of the Southern Recreation Research Conference, Myrtle Beach, SC, USA, 28 February-1 March 1985; pp. 1-15. 
21. Spennemann, D. Extreme cultural tourism, from Antarctica to the Moon. Ann. Tour. Res. 2007, 34, 898-918. [CrossRef]

22. International Association of Antarctica Tour Operators. Antarctica Tourism Fact Sheet 2016-2017. Retrieved 25 January 2017. Available online: https: / /iaato.org/documents/10157/25111/IAATO+Facts+Sheet+201617.pdf/718a90a9-ba04-4890-826b-d63b269dce52 (accessed on 20 November 2017).

23. Zeppel, H.; Muloin, S. Education and conservation benefits of interpretation on marine wildlife tours. Tour. Mar. Environ. 2008, 5, 215-228. [CrossRef]

24. Vila, M.; Costa, G.; Angulo-Preckler, C.; Sarda, R.; Avila, C. Contrasting views on Antarctic tourism: 'Last chance tourism' or 'ambassadorship'. J. Clean. Prod. 2016, 111, 451-460. [CrossRef]

25. Eijgelaar, E.; Thaper, C.; Peeters, P. Antarctic cruise tourism: The paradoxes of ambassadorship, 'last chance tourism' and greenhouse gas emissions. J. Sustain. Tour. 2010, 18, 337-354. [CrossRef]

26. Dowling, R.K. Tourism in the Antarctic: Opportunities, Constraints, and Future Prospects; The Haworth Hospitality Press: New York, NY, USA, 2001; Volume 24, pp. 345-346.

27. Oppermann, M. What is New with the resort cycle? Coment. Tour. Manag. 1998, 19, 181-183. [CrossRef]

28. Defert, P. Essaie de localization touristique. Tour. Rev. 1954, 9, 119.

29. Haywood, K.M. Evolution of tourism areas and the tourism industry. In The Tourism Area Life Cycle, Applications and Modifications; Butler, R.W., Ed.; Channel View Publications: Clevedon, NY, USA; Buffalo, NY, USA; Toronto, ON, Canada, 2006; Volume 1, pp. 51-70.

30. Kapczyński, A.; Szromek, A.R. Hypotheses concerning the development of Polish spas in the years 1949-2006. Tour. Manag. 2008, 29, 1035-1037. [CrossRef]

31. Corak, S. The modification of the tourism area life cycle model for re(inventing) a destination: The case of the Opatija Riviera, Coatia. In The Tourism Area Life Cycle, Applications and Modifications; Butler, R.W., Ed.; Channel View Publications: Clevedon, NY, USA; Buffalo, NY, USA; Toronto, ON, Canada, 2006; Volume 1, pp. 271-288.

32. Lundtorp, S.; Wanhill, S. Time path analysis and TALC stage demarcation. In The Tourism Area Life Cycle, Conceptual and Theoretical Issues; Butler, R.W., Ed.; Chanel View Publications: Clevedon, NY, USA; Buffalo, NY, USA; Toronto, ON, Canada, 2006; Volume 2, pp. 138-149.

33. Lagiewski, R.M. The application of the TALC model: A literature survey. In The Tourism Area Life Cycle; Butler, R.W., Ed.; Channel View Publications: Clevedon, NY, USA; Buffalo, NY, USA; Toronto, ON, Canada, 2006; p. 27.

34. Diedrich, A.; Garcia-Buades, E. Local perceptions of tourism as indicators of destination decline. Tour. Manag. 2009, 30, 512-521. [CrossRef]

35. Rostow, W.W. Stages of economic growth. Econ. Hist. Rev. New Ser. 1959, 12, 1-16. [CrossRef]

36. Kotler, P.; Turner, R.E. Marketing Management; Prentice-Hall: Woodbridge, ON, Canada, 1993; pp. $3271-3397$.

37. Butler, R.W. The resort cycle two decades on. In Reflections on Experience; Faulkner, B., Laws, E., Morcado, G., Eds.; Cassell: London, UK, 2000; pp. 284-298.

38. Oreja Rodriguez, J.R.; Parra-Lopez, E.; Yanes-Estavez, V. The sustainability of island destinations: Tourism area life cycle and teleological perspectives. The case of Tenerife. Tour. Manag. 2008, 29, 53-65. [CrossRef]

39. Haywood, K.M. Can the tourist area life-cycle be made operational? Tour. Manag. 1986, 7, 154-167. [CrossRef]

40. Lundgren, J.O. An empirical interpretation of the TALC: Tourist Product Life Cycles in the Eastern Townships of Quebec. In The Tourism Area Life Cycle, Applications and Modifications; Butler, R.W., Ed.; Channel View Publications: Clevedon, NY, USA; Buffalo, NY, USA; Toronto, ON, Canada, 2006; Volume 1, pp. 91-106.

41. Weaver, D.; Lawton, L. Tourism Management III; John Widley \& Sons: Milton, Australia, 2006; p. 324.

42. Johnston, C.S. Shoring and foundations of the destination life cycle model, Part 1: Ontological and epistemological considerations. Tour. Geogr. 2001, 3, 2-28. [CrossRef]

43. U.S. Department of State. Available online: https://www.state.gov/documents/organization/15272.pdf (accessed on 20 November 2017).

44. Secretariat of the Antartic Treaty. Available online: http://www.ats.aq/index_e.htm (accessed on 20 November 2017).

45. International Association Antarctic Tour Operators. Available online: https://iaato.org/documents/10157/ 25111/IAATO+Fact+Sheet+2017-18.pdf (accessed on 20 November 2017).

46. Szeligowicz, W. The Antarctic Ecosystem-A destination for exotic adventure tourism. Tour. Recreat. 2006, 2, $5-11$. 
47. International Association Antarctic Tour Operators. Available online: http:/ /iaato.org/tourism-overview (accessed on 9 October 2017).

48. International Association Antarctic Tour Operators. Available online: http://iaato.org/current-iaatoinformation-papers (accessed on 20 November 2017).

49. Ciaputa, R.; Salwicka, K. Tourism at Antarctic Station 1991-1997. Policies for better management. Pol. Polar Res. 1997, 18, 227-239.

50. White, K.J. Tourism and the Antarctic economy. Ann. Tour. Res. 1994, 21, 245-268. [CrossRef]

51. House, J. From explorers to mass tourists. Ann. Tour. Res. 2000, 27, 531-533. [CrossRef]

52. Telfer, D.J. People and tourism in fragile environments. Tour. Manag. 1997, 18, 405-407. [CrossRef]

53. Anisimov, O.A.; Vaughan, D.G.; Callaghan, T.V.; Furgal, C.; Marchant, H.; Prowse, T.D.; Vilhjamsson, H.; Walsh, J.E. Polar regions (Arctic and Antarctic). Climate Change: Impacts, Adaptation and Vulnerability. In Contribution of Working Group II to the Fourth Assessment Report of the Intergovernmental Panel on Climate Change; Cambridge University Press: Cambridge, UK, 2007; pp. 653-685.

54. Antartic and Southern Ocean Coalition. Available online: http://www.asoc.org/advocacy/climate-changeand-the-antarctic (accessed on 9 October 2017).

55. Butler, R.W. Tourism, environment, and sustainable development. Environ. Conserv. 1991, 18, $201-209$. [CrossRef]

56. Gyimóthy, S.; Mykletun, R.J. Play in adventure tourism. The case of Arctic trekking. Ann. Tour. Res. 2004, 31, 855-878. [CrossRef]

57. Kruczek, Z.; Kruczek, M. Contemporary Dilemmas of Tourism Development in the Himalayan Kingdom of Bhutan. In Mountains-Man-Tourism; Cybula, P., Czyż, M., Owsianowska, S., Eds.; Proksenia: Kraków, Poland, 2011; pp. 381-390, ISBN 978-83-60789-38-4.

58. Nyaupane, G.P.; Timothy, D.J. Power, Regionalism and Tourism Policy in Bhutan. Ann. Tour. Res. 2010, 37, 969-988. [CrossRef]

59. Apollo, M. The true accessibility of mountaineering: The case of the High Himalaya. J. Outdoor Recreat. Tour. 2017, 17, 29-43. [CrossRef]

(C) 2018 by the authors. Licensee MDPI, Basel, Switzerland. This article is an open access article distributed under the terms and conditions of the Creative Commons Attribution (CC BY) license (http://creativecommons.org/licenses/by/4.0/). 